\title{
Coronavirus Disease 2019: Prevention and Safety in the Dental Office
}

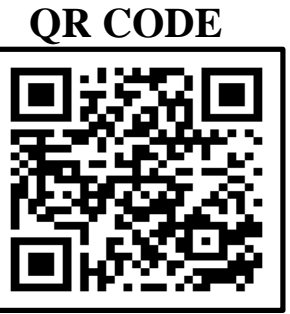

\section{PRIYANKA', SONAL PRIYA BHANSALI², SUMIT BHANSALI³ ${ }^{3}$ YAGYESHWAR MALHOTRA*4 (Corresponding Author)}

Coronavirus disease 2019 (COVID-19) caused by a single stranded RNA virus originating from Wuhan China has gripped the whole world and evolved rapidly into a public health crisis. SARSCoV-2 (severe acute respiratory syndrome coronavirus 2 is abundantly present in nasopharyngeal and salivary secretions of affected patients and is transmitted by droplets, surface contact, fecal-oral route and by aerosolization during procedures. The dental professionals are particularly at risk because of close contact with the patient and exposure to blood, saliva and droplets. Dental professionals must be fully aware of coronavirus spreading modalities, identification of patients with this infection, so present article introduces the essential knowledge about COVID-19 infection and provide recommended management protocols for dental practitioners based on relevant guidelines, research so that dental professional are better prepared to manage asymptomatic, suspected, and confirmed COVID-19 patients.

KEYWORDS: Coronavirus, Saliva, Disinfection, Triage

\section{INTRODUCTION}

What a start for year 2020: coronavirus. Corona virus disease also known as COVID 19 has rapidly evolved into a worldwide health crisis influencing every aspect of life. The corona virus infection started from Wuhan, China and was declared pandemic by world health organization., ${ }^{1,2}$ The novel corona virus was initially named 2019-nCoV and officially called SARSCoV-2 (severe acute respiratory syndrome coronavirus-2.3 On $11^{\text {th }}$ February 2020, World health organization named the latest strain of coronavirus as COVID 19. ${ }^{4}$ This novel coronavirus is similar to coronavirus species found in bats and pangolins stating zoonotic nature of this disease. ${ }^{5,6}$ Globally, as of $7^{\text {th }}$ February 2021, there have been 105,394,301 confirmed cases of COVID-19, including 2,302,303 deaths and India has reported $10,826,363$ confirmed cases of COVID-19 with 154, 996 deaths as reported by WHO situation report and number is increasing each day [Figure 1].7 When COVID-19 infection was spreading at an alarming rate, many countries including India imposed lockdown to control the spread of the infection by closing teaching institutions, airports, social gatherings, sports activities, events, bus transport and offices with special guidelines. Besides this, several individuals were selfquarantined and many with travelling history from affected areas were home or institution quarantined to limit the spread of disease.

Health care professionals including dental professionals working as corona warriors are in close contact with infected patients and have highest chance of getting infected. ${ }^{8,9}$ Many health care workers like doctors, nurses have been tested positive for COVID19, many are quarantined and deaths have also been reported from affected countries including India. Dental professionals have a high risk of getting infected and potentially spreading it to their peers, families, other patients and can become potential carriers of the disease..$^{-12}$ As viruses can be easily vehiculated by the aerosol generated by most of dental procedures so the aim of the present article is to introduces the essential knowledge about COVID-19 infection in dental settings and provide recommended management protocols for dental practitioners based on relevant guidelines and research so dental professional are better prepared to manage asymptomatic, suspected, confirmed COVID19 patients.

\section{EPIDEMIOLOGY AND PATHOGENESIS}

Genetic and epidemiologic research shows that COVID-19 infection started with a single animal-tohuman transmission, followed by sustained human-tohuman spread. ${ }^{13,14}$ The common routes of transmission of coronavirus includes direct transmission of respiratory droplets from infected person while speaking, coughing, sneezing to the mouth, nose or eyes or by inhalation into lungs of nearby individuals. ${ }^{15,16}$ SARS-CoV-2 can bind to human 


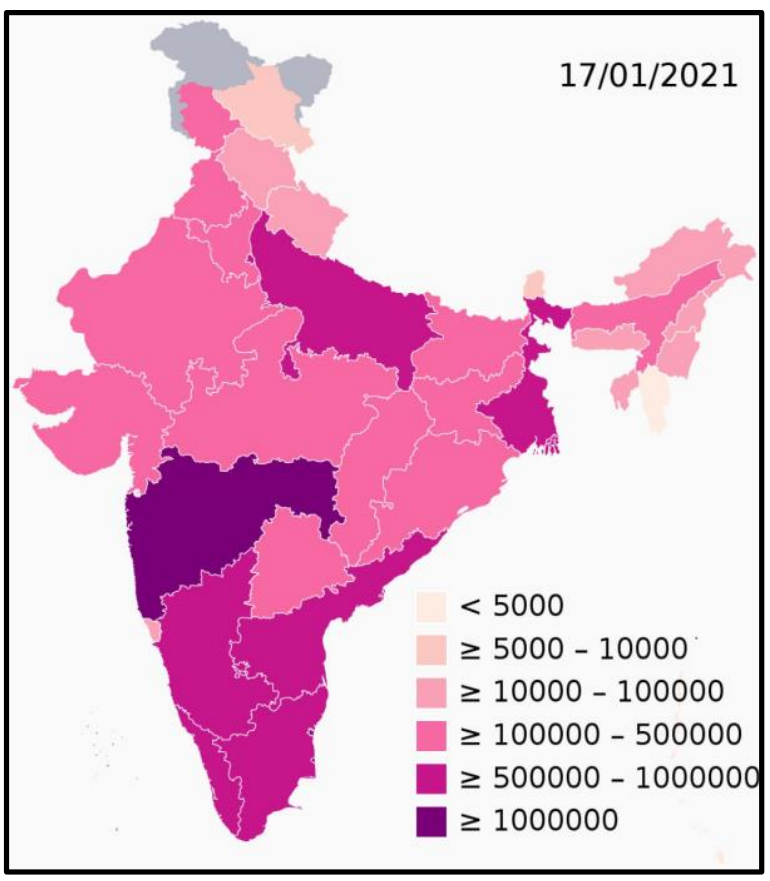

Figure 1. India COVID-19 case density map on 17-012021

angiotensin-converting enzyme 2 receptors, which are highly concentrated in salivary glands explaining presence of SARS-CoV-2 in secretary Saliva [Figure 2]. ${ }^{17^{-}}$

${ }_{19}$ Coughing or sneezing by an infected person makes SARS-CoV-2 Airborne, leading to recommendation of social distancing to minimize community spread of the disease. In addition, there may be risk of fecal-oral Transmission, as SARS-CoV-2 was found in the stool of patients. ${ }^{20}$ Symptomatic COVID-19 patients are the main source of transmission but asymptomatic patients andopatients in their incubation period are also carriers of SARS-CoV-2. ${ }^{13,21}$ The average incubation period has been found to be 5- 6 days, but it could be as long as 14 days, which is the time duration adopted for medical observation and quarantine. ${ }^{22,23}$ People of all ages are generally susceptible to this disease but elders with pre-existing chronic diseases like cardiovascular illness, kidney diseases or immunosuppression and close contacts of COVID-19 infected patients including health care workers are at higher risk of COVID-19 infection. ${ }^{24,25}$ Dental care settings invariably carry the risk of infection transmission due to the specificity of its procedures. Pathogenic microorganisms can be transmitted through inhalation of airborne microorganisms, direct exposure of respiratory secretions containing blood, oral fluids and nasal, oral and conjunctival mucosal contact with droplets and aerosols. Indirect transmission can occur by contact with contaminated instruments and clinical environmental surfaces [Figure 3]. ${ }^{11,26-30}$

\section{CLINICAL MANIFESTATIONS}

Patients with COVID-19 usually present with clinical symptoms of fever, dry cough, shortness of breath, myalgia and fatigue [Figure 4]. In addition, symptoms like nausea, diarrhoea, vomiting, sore throat, headache, reduced sense of smell, and abnormal taste sensation has also been observed. ${ }^{13,31,32}$ In addition, chest X-ray and computed Tomography demonstrated groundglass Opacities and bilateral shady patches as most common pattern. ${ }^{33}$ Most of the patients have only mild symptoms resembling flu like symptoms and seasonal allergies. ${ }^{33}$ Asymptomatic patients can act as potential carriers and source of re-infection. The higher-risk patient population manifests symptoms typical of pneumonia or zacute respiratory distress Syndrome. ${ }^{34}$

\section{DIAGNOSIS AND TREATMENT PLAN}

The diagnosis of COVID-19 is based on a combination of epidemiologic information, clinical symptoms, laboratory tests and CT imaging findings.9,34 Novel coronavirus nucleic acid can be detected in nasopharyngeal swabs, oropharyngeal swabs, sputum, lower respiratory tract secretions, blood, feces, and

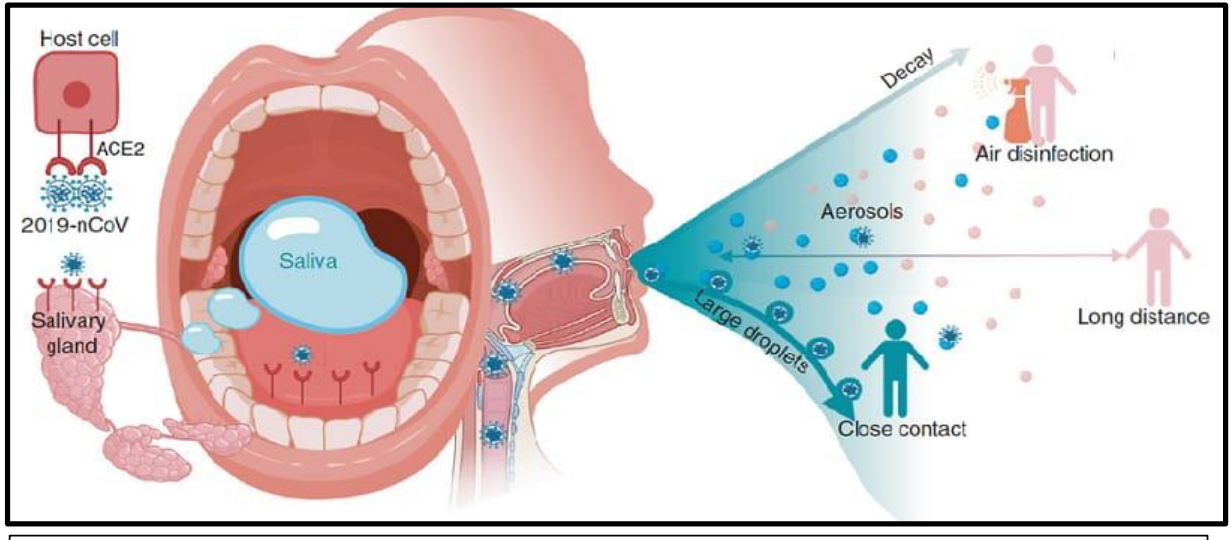

Figure 2. Potential diagnostic value of saliva and transmission of 2019-nCoV 


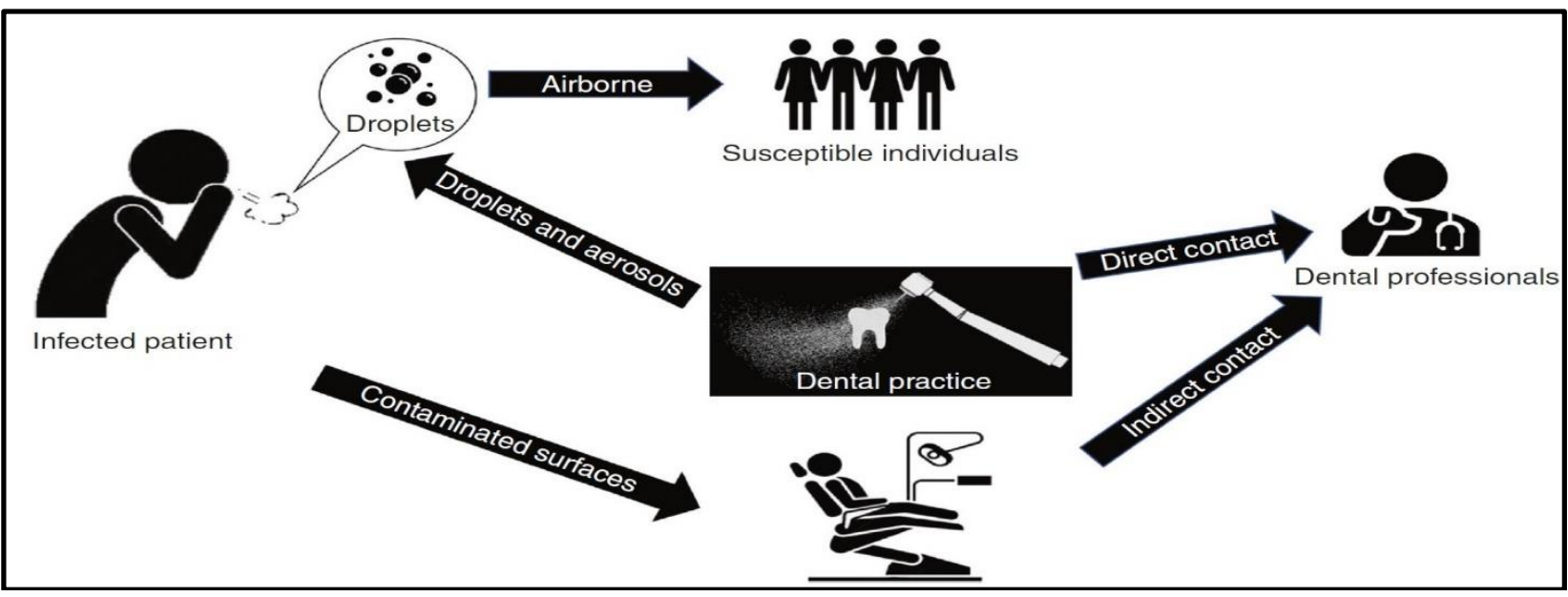

Figure 3. Transmission routes of 2019-nCoV in dental clinics and hospitals

bronchoalveolar lavage using RT-PCR and/or NGS methods. Serological diagnosis of COVID-19 using SARS-CoV-specific secretary immunoglobulin A (SIgA) in saliva has also been demonstrated. ${ }^{5}$ Researchers had carried out various testing and clinical trials to investigate interventions that were potentially effective against COVID-19 and various medications were recommended for prophylaxis of SARS-CoV-2 infection in selected high-risk individuals. ${ }^{36}$ The convalescent plasma $(\mathrm{CP})$ use as a potential treatment modality is still questionable due to limited high-quality randomized clinical trial studies. ${ }^{37,38}$ Now corona vaccine is available and it is being given to the people in different countries. COVID-19 management has largely been supportive and is directed at relieving symptoms. ${ }^{9}$ The COVID-19 vaccine was launched on $16^{\text {th }}$ January, 2021 in India. ${ }^{17}$ Healthcare and frontline workers are getting the vaccine in first phase and will be followed by persons over 50 years of age and persons under 50 years with comorbid conditions.

\section{PATIENT MANAGEMENT IN DENTAL PRACTICE}

As many of the dental procedures involve aerosol generating procedures, the standard protective measures followed in routine clinical work are not sufficient to prevent the spread of COVID-19 infection. Different kinds of patients like Asymptomatic patients, patients in incubation period, unaware of their infection, or choose to conceal their infection can visit for treatment. With increase in cases daily and fear of community spread it is strongly recommended to treat each dental patient as COVID-19 positive.

\section{TELE SCREENING AND TRIAGE}

1. In general, one should avoid walk-in visits.

2. Phone triage of every patient should be carried out at the time of scheduling appointments. When patient arrives at dental clinic a detailed medical history, COVID-19 screening questionnaire to identify any suspected or possible infected COVID-19 patient and assessment of true dental emergency should be done by asking patient about the nature of his dental condition. 39

\section{HOW TO IDENTIFY DENTAL EMERGENCY}

When a patient calls or visit dental clinic, dentists should use their professional judgment ${ }^{8}$ to decide if a patient need emergency, urgent or non-urgent dental care. ${ }^{40,41}$ Dental emergencies are potentially life threatening and require immediate intervention and include:

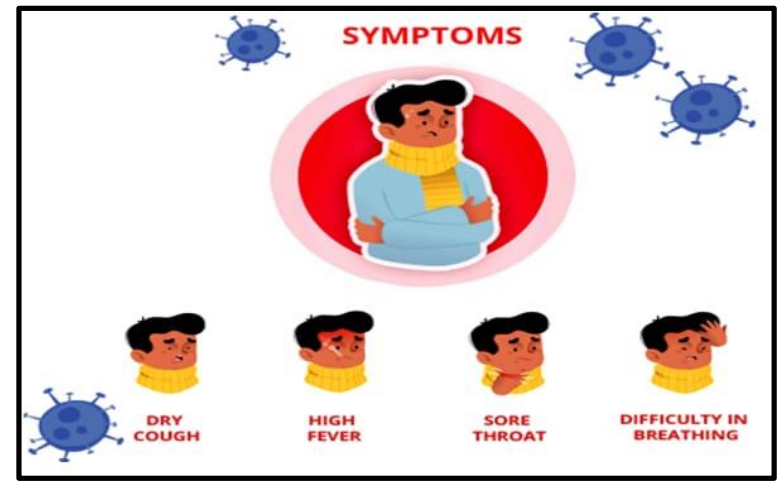

Figure 4. Sign and symptoms of COVID-19 
1. Uncontrolled bleeding.

2. Cellulitis or a diffuse soft tissue bacterial infection with intra-oral or extra-oral swelling that potentially compromise the patient's airway.

3. Trauma involving facial bones, potentially compromising the patient's airway.

Urgent dental care involves conditions that require immediate attention to relieve severe pain and/or risk of infection. These should be treated as minimally invasively as possible.

1. Severe dental pain from pulpal inflammation.

2. Pericoronitis or third-molar pain.

3. Surgical post-operative osteitis, dry socket dressing changes.

4. Abscess, or localized bacterial infection resulting in localized pain and swelling

5. Tooth fracture resulting in pain or causing soft tissue trauma.

6. Dental trauma with avulsion/luxation.

7. Dental treatment required prior to critical medical procedures.

8. Final crown/bridge cementation if the temporary restoration is lost, broken or causing gingival irritation. 9. Biopsy of abnormal tissue.

Other urgent dental care:

1. Extensive dental caries or defective restorations causing pain.

2. Suture removal.

3. Denture adjustment on radiation/ oncology patients.

4. Denture adjustments or repairs when function impeded.

5. Replacing temporary filling on endodontic access openings in patients experiencing pain.

6. Snipping or adjustment of an orthodontic wire or appliances piercing or ulcerating the oral mucosa.

\section{ROUTINE OR NON-URGENT DENTAL PROCEDURES INCLUDE BUT ARE NOT LIMITED TO:}

1. Initial or periodic oral examinations and recall visits, including routine radiographs.

2. Routine dental cleaning and preventive therapies.

3. Orthodontic procedures other than those to address acute issues (e.g. pain, infection, trauma) or other issues critically necessary to prevent harm to the patient.

4. Extraction of asymptomatic teeth.

5. Restorative dentistry including treatment of asymptomatic carious lesions.

6 . Aesthetic dental procedures.

Treatment should be deferred for two weeks in 2suspected or confirmed cases of COVID 19 infection if possible and the patient should be reported to the concerned health authorities to quickly impose quarantine and/or hospitalization depending on the severity of the situation.9,41,42,43,44 Positive cases requiring emergency treatment should be referred preferably to emergency department with dental consult. If the dentist cannot delay the treatment or refer the patient then one should follow standard, contact and airborne precautions while treating the patient in negatively pressured rooms or Air Borne Infection Isolation Rooms (AIIRs) if available. ${ }^{11,45}$ Urgent care should be deferred if possible for at least 2 weeks and antibiotics and/or analgesics should be prescribed for dental conditions like tooth pain and/or swelling. In case of asymptomatic patients with contact or travel history treatment should be postponed up to 14 days if possible. If there is no history of contacts and/or symptoms, patients are allowed to visit the dental office with modifications and dental procedures should be performed by following the preventive precautions [Figure 5].

\section{DENTAL OFFICE TRIAGE}

1. Patient entering the dental office should be given a surgical mask if he/she is not wearing one.

2. Patients are advised to arrive on time for appointments, not early, to minimize waiting in dental office and to decrease the number of people present.

3. Physical barriers made up of glass or plastic windows should be installed at reception areas to limit close contact with potentially infectious patients.

4. Patient's history should be repeated and body temperature registered through $7 \mathrm{a}$ no contact forehead thermometer. ${ }^{11}$

5. Suspected or confirmed ipatients of COVID-19 infection should be seated in a separate, wellventilated waiting area and should follow proper respiratory hygiene. 45

6. A prominent sign directing the patients to use a hand sanitize from no touch dispenser should be placed at entrance.

7. Posters and signs about hand hygiene, respiratory hygiene, social distancing and cough etiquette should be displayed at the entrance, waiting areas, 


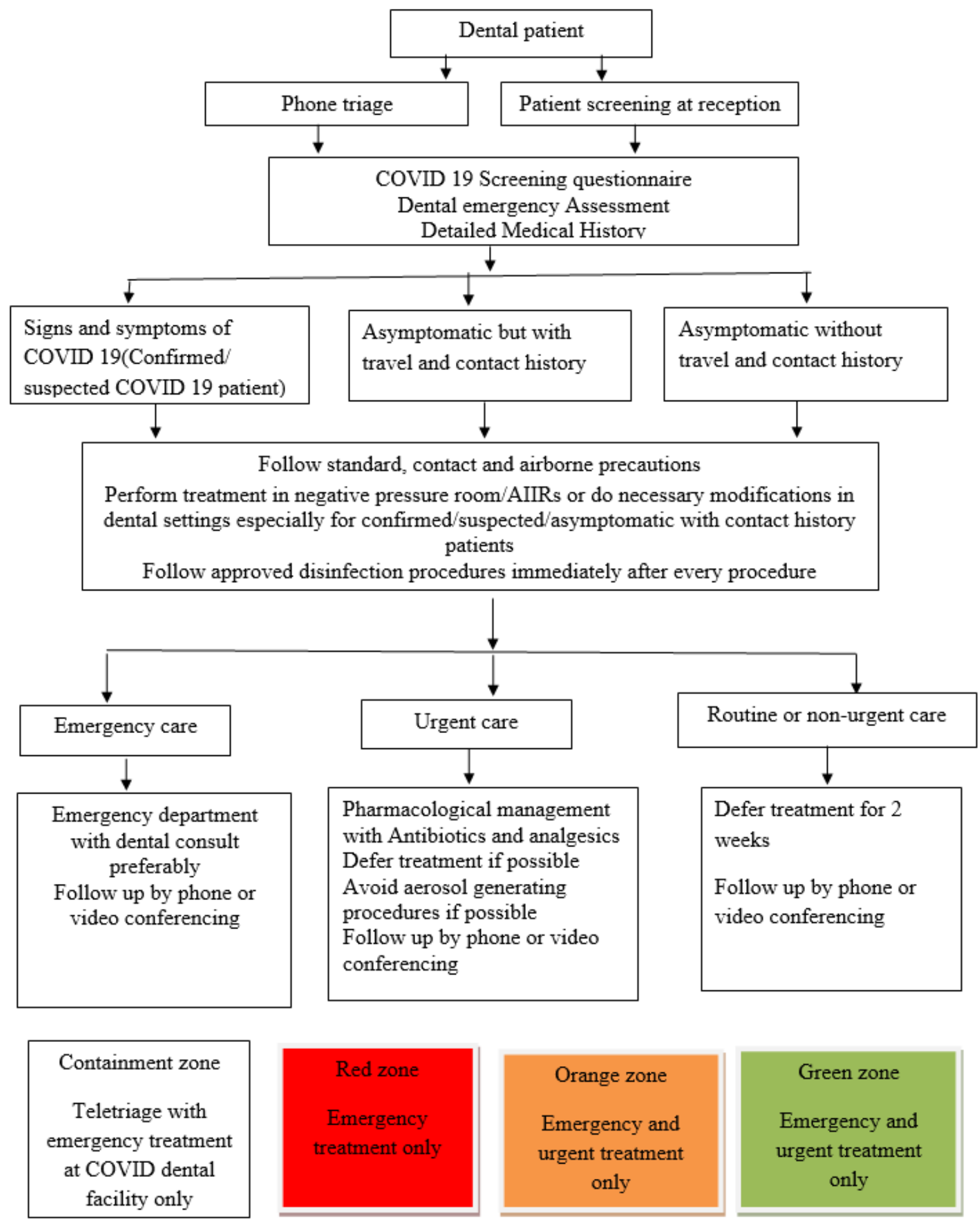

Figure 5. An overview of patient screening and management in dental office 
elevators, and cafeteria. ${ }^{47,48}$

8. Remove all potentially contaminated objects (i.e., tables, magazines, toys) which could facilitate cross infection.

9. Number of patients should be limited in waiting area and distance of one meter should be kept between the chairs. ${ }^{49}$ Accompanying persons should be advised to wait outside the dental office.

10. Clothing, cellular telephones, and bags are encouraged to be left in the waiting room. Public areas, including door handles, chairs and bathrooms should be cleaned and disinfected frequently.

\section{DENTAL TREATMENT GUIDELINES}

Dental treatment may pose significant risks for dental practitioners and patients. Every dental patient appearing healthy 8should be considered contagious as the person can be possessing virus despite the absence of clinical manifestations. During dental procedures involving production of aerosols there is a risk of inhalation of small particles and droplets potentially carrying microorganisms by the dental workers so, it is important to safeguard our patients' health via establishing contagion risk reduction protocol and a safer work environment.

1. Pre-procedural one minute mouth rinse with $0.2 \%$ to $1 \%$ povidone-iodine, $0.05 \%$ to $0.1 \%$ cetylpyridinium chloride, or.5- $1 \%$ hydrogen peroxide before dental procedure is one of the most efficient ways to reduce the proportion of microorganisms in oral cavity. ${ }^{11,50}$

2. The dental practitioner should perform careful hand washing using alcohol based formulations or water and soap for at least 20 seconds.[51]. The department for infections control of the Stomatology Hospital in West China (Sichuan University) proposed a "two-before and three-after" protocol for hands hygiene."

3. Dental practitioners should follow all the standard, contact, and airborne precautions including 2the appropriate use of personal protective equipment including long-sleeved water resistant gown, face masks, glasses or face shield, overshoes, head cap. Face masks like National Institute for Occupational Safety and Health-certified N95, European Standard Filtering Face Piece 2 (EU FFP2), or equivalent, when running aerosol generation procedures and $\mathrm{EU} \mathrm{FFP}_{3}$ respirators complying with European Standard 149 (EN 149) or equivalent should be used during emergency for ssuspected or confirmed COVID-19 patients. There should be a dedicated area for donning and doffing of PPE.[51,52,53]
4. Disposable (single-use) devices such as mouth mirror, syringes, and blood pressure cuff should be used to prevent cross contamination.

5. Dental instruments required in a dental procedure should be prepared in advance to make the procedure fast and limit contamination.

6 . Working surfaces, the dental chair, and devices can be protected from direct contamination by using disposable coverings.

7. Extra oral imaging techniques like panoramic radiography or cone-beam computed tomographic imaging should be preferred than intraoral to avoid gag or cough. ${ }^{9}$ If intraoral imaging is unavoidable, sensors should be double Covered to prevent perforation and cross contamination.

8. Rubber dam should be used to minimize splatter generation and extra high volume suction should be used to prevent spreading of aerosol and spatter. Use of a complete four-handed operatory is also desirable. ${ }^{54,55}$

9. Ultrasonic instruments, high-speed handpieces, and 3-way syringes should be used minimal to reduce the risk of generating contaminated aerosols. Antiretraction dental hand piece with specially designed anti-retractive valves or other anti-reflux designs are strongly recommended. 55

10. Digital dental impressions should be preferred over traditional ones and traditional impressions should be immediately disinfected with the use alcohol based disinfectants sealed in an envelope and sent to the laboratory. Since cast models are usually contaminated with many microbial species and zare difficult to sanitize, prefer models made of synthetic materials. ${ }^{56}$

11. Dentists should minimize utilizing rotary instruments for preparing a cavity and atraumatic restorative procedures can be done in selective cases. Pulp devitalization can be performed for a carious tooth with symptomatic irreversible pulpitis, followed by filling material.

12. Treatment of fracture, luxation, or avulsion of tooth should be decided by the age, trauma severity, apex formation and duration of tooth avulsion. If suturing is needed absorbable suture is preferred.

13. Cases with severe oral and maxillofacial compound injuries should be admitted to the hospital immediately and treated accordingly.

14. After the procedure, all the disposable protections should be removed. The reusable tools and materials should be cleansed, sterilized, and carefully preserved.

15. As coronavirus may live up to 9 days on an inert 
surface with preference for humid condition clinical staff should disinfect inert surfaces using chemicals effective against COVID-19 and keep a dry atmosphere to mitigate the 2019 -nCoV spread. ${ }^{27,57}$ Recent WHO guidelines deemed water and detergent followed by disinfectants (.1\% sodium hypochlorite or $5 \%$ bleach 1:50 dilution) effective against COVID-19..$^{8}$

16. Ventilation systems providing air movement from a clean (DHCP workstation or area) to contaminated (clinical area) direction should be installed and properly maintained. Use of indoor portable air cleaning system equipped with HEPA filter and UV light is advisable.

17. The medical and domestic waste produced after treatment of suspected or confirmed COVID-19 cases is considered to be infectious medical waste and should be disposed off in a double-layer yellow waste bags with a "gooseneck" knot in compliance with the requirements of medical waste disposal.

\section{CONCLUSION}

With rampant 8spread of COVID-19 infection worldwide and cases increasing, dental care professionals now will be treating this subset of patient population on daily basis. Several dental practices have either modified their services according to recommended guidelines, or closed down practices for an uncertain period causing serious financial challenges impacting economical condition of the sector. Dental professionals must be fully aware of 2019-nCoV spreading modalities, identification 2 of COVID-19 patients, most importantly self-protection, protection of people and adoption of strict preventive measures. Corona vaccines are available and being administered phase wise but Covering the whole population especially in India is a challenge. Dentistry has an important role to play during this pandemic so further assessment of the implications of COVID-19 outbreak in dental practice is urgently needed and in coming time entire profession might show a significant change.

\section{REFERENCES}

1. Phelan AL, Katz R, Gostin LO. The novel coronavirus originating in Wuhan, China: challenges for global health governance. JAMA 2020; 323: 709-10.

2. World Health Organization (WHO) Coronavirus Disease (COVID-19) Pandemic. (Online Article): Available

https://wwwwhoint/emergencies/diseases/novelcoronavirus-2019. [Last Accessed on $15^{\text {th }}$ January, 2021]
3. Gorbalenya AE, Baker SC, Baric RS, Groot RJ. The species Severe acute respiratory syndrome related coronavirus: classifying $2019-\mathrm{nCoV}$ and naming it SARS-CoV-2. Nat Microbiol. 5(5) 2020. https://doi.org/10.1038/s41564-020-0695-z.

4. Mahase E. China coronavirus: WHO declares international emergency as death toll exceeds 200. BMJ. https://doi.org/10.1136/bmj.m4o8.

5. Zhou P, Yang X-L, Wang X-G, Hu B , Zhang L , Zhang W, et al. A pneumonia outbreak associated with a new coronavirus of probable bat origin. Nature 2020;579:270-3.

6. Wahba L, Jain N, Fire AZ, Shoura MJ, Artiles KL, McCoy MJ,et al. Identification of a pangolin niche for a 2019-nCoV-like coronavirus through an extensive meta metagenomic search. BioRxiv 2020. https://doi.org/10.1101/2020.02.08.93966o.

7. World Health Organisation- coronavirus disease (COVID-19) situation report -283

8. Ather A, Patel B, Ruparel NB, Diogenes A, Hargreaves K.M. Coronavirus Disease 19 (COVID-19): Implications for Clinical Dental Care. J Endod. 2020;46:1-11.

9. Meng L, Hua F, Bian Z. Coronavirus Disease 2019 (COVID-19): Emerging and Future Challenges for Dental and Oral Medicine. J Dent Res. 2020;99(5):4817 .

10. Gamio L. The workers who face the greatest risk. The New York Times. Online Article. Available from: https://www.nytimes.com/interactive/2020/03/15/busin ess/economy/coronavirus-worker-risk.html. [Last Accessed on February $1^{\text {st }}$, 2021.]

11. Peng $\mathrm{X}, \mathrm{Xu} \mathrm{X}, \mathrm{Li} \mathrm{Y}$, Cheng L, Zhou X, Ren B. Transmission routes of $2019-\mathrm{nCoV}$ and controls in dental practice. Int J Oral Sci. 2020;12(1):9. https://doi.org/10.1038/s41368-020-0075-9.

12. Xu H, Zhong L, Deng J, Peng J, Dan H, Zeng X, Li T, et al. High expression of ACE2 receptor of 2019-nCoV on the epithelial cells of oral mucosa. Int J Oral Sci. 2020; 12(1):8. https://doi.org/10.1038/s41368-020-0074$\mathrm{x}$.

13. Chen N, Zhou M, Dong X, Qu J, Gong F, Han Y, et al. Epidemiological and clinical characteristics of 99 cases of 2019 novel coronavirus pneumonia in Wuhan, China: a descriptive study. Lancet 2020; 395:507-13. https://doi.org/10.1016/So140-6736(20)30211-7.

14. Rio DC, Malani PN. 2019 novel coronavirusimportant information for clinician. JAMA 2020;23(11):1039-40.

https://doi.org/10.1001/jama.2020.1490. 
15. Centers for Disease Control and Prevention. Transmission of coronavirus disease 2019 (COVID). (Online Article). Available from: https://www.cdc.gov/coronavirus/2019nCoV/about/tra nsmission.html. [Last Accessed on February 25 ${ }^{\text {th }}$, 2021.] 16. Lu CW, Liu XF, Jia ZF. 2019-nCoV transmission through the ocular surface must not be ignored. Lancet. $\quad 2020 \quad$;395 (10224):e39 https://doi.org/10.1016/So140-6736(20)30313-5 17. To KK, Tsang OT, Yip CC, Chan K, Wu T, Chan JMC, et al. Consistent detection of 2019 novel coronavirus in saliva. Clin Infect Dis. 2020;ciaal49. https://doi.org/10.1093/cid/ciaa149.

18. Xu R, Cui B, Duan X, Zhang P, Zhou X and Yuan Q. Saliva: potential diagnostic value and transmission of 2019-nCoV. Int J of Oral Sci. 2020;12(1):11. https://doi.org/10.1038/s 41368-020-0o8o-z.

19. Sabino-Silva R, Jardim ACG, Siqueira WL. Coronavirus COVID-19 impacts to dentistry and potential salivary diagnosis. Clin Oral Investig. 2020:13. https://doi.org /10.1007/s00784-020-03248-x.

20. Zhang J, Wang S, Xue Y. Fecal specimen diagnosis 2019 novel coronavirus-infected pneumonia. J Med Virol. 2020;92:68o-2. https://doi.org/10.1002/jmv.25742 21. Rothe C, Schunk M, Sothmann P,Gisela Bretzel G,Froeschl G, Wallrauch C, et al. Transmission of 2019$\mathrm{nCoV}$ infection from an asymptomatic contact in Germany. N Engl J Med. 2020;382:970-1. https://doi.org/10.1056/NEJMc2001468

22. Backer JA, Klinkenberg D, Wallinga J. Incubation period of 2019 novel coronavirus (2019-nCoV) infections among travellers from Wuhan, China, 20-28 January 2020.Euro Surveill. 2020;25(5):2000062. https://doi.org/10.2807/1560-7917.ES.2020.25.5.20000 62.

23. Li Q, Guan X, Wu P, Wang X, Zhou L, Tong Y, et al. Early transmission dynamics in Wuhan, China, of novel coronavirus-infected pneumonia. N Engl J Med.2020;382(13):1199-207.

https://doi.org/10.1056/NEJMoa20o1316.

24. Wang D, Hu B, Hu C, Zhu F, Liu X, Zhang J, et al. Clinical characteristics of 138 hospitalized patients with 2019 novel coronavirus-infected pneumonia in Wuhan, JAMA 2020;323: 1061-9. https://doi.org/10.1001/jama.2020.1585

25. Yang Y, Lu Q, Liu M, Wang Y, Zhang A, Jalali N, et al. Epidemiological and clinical features of the 2019 novel coronavirus outbreak in China. medRxiv. https://doi.org/10.1101/2020.1102.1110.20021675.

26. Liu L, Liu L, Wei Q, Alvarez X, Wang H, Du Y, Zhu $\mathrm{H}$, et al. Epithelial cells lining salivary gland ducts are early target cells of severe acute respiratory syndrome coronavirus infection in the upper respiratory tracts of rhesus macaques. Journal of Virology 2011;85(8):402530; https://doi.org/10.1128/JVI.02292-10

27. Kampf G, Todt D, Pfaender S, Steinmann E. Persistence of coronaviruses on inanimate surfaces and its inactivation with biocidal agents. J Hosp Infect. 2020;104:246-51.

https://doi.org/10.1016/j.jhin.2020.01.022

28. Chen J. Pathogenicity and transmissibility of 2019$\mathrm{nCoV}-\mathrm{a}$ quick overview and comparison with other emerging viruses. Microbes Infect. 2020;22:69-71. https://doi.org/10.1016/j.micinf.2020.01.004

29. Cleveland JL, Gray SK, Harte JA,Robison VA, Moorman AC, Gooch BF. Transmission of blood-borne pathogens in US dental health care settings: 2016 update. J Am Dent Assoc.2016;147:729-38. https://doi.org/10.1016/j.adaj.2016.03.020

30. Harrel SK, Molinari J. Aerosols and splatter in dentistry: a brief review of the literature and infection control implications. J Am Dent Assoc. 2004;135(4): 429-37.

https://doi.org/10.14219/jada.archive.2004.0207

31. Huang C, Wang Y, Li X, Ren L, Zhao J, Hu Y, et al . Clinical features of patients infected with 2019 novel coronavirus in Wuhan, China. Lancet. 2020;395:497506. https://doi.org/10.1016/So140-6736(20)30183-5.

32. Giacomelli A, Pezzati L, Conti F, Bernacchia D, Siano M, Oreni L, et al. Self-reported olfactory and taste disorders in SARSCoV- 2 patients: a crosssectional study. Clin Infect Dis. 2020;ciaa33o. https://doi.org/10.1093/cid/ciaa330.

33. Guan W-J, Ni Z-Y, Hu Y, Liang W-H, Ou C-Q, He J$\mathrm{X}$, et al. Clinical characteristics of 2019 novel coronavirus infection in China. $\mathrm{N}$ Engl J Med. 2020;382:1708-20.

https://doi.org/10.1056/NEJMoa2002032

34. World Health Organization. Clinical Management of Severe Acute Respiratory Infection When Novel Coronavirus (2019-nCoV) Infection Is Suspected: Interim Guidance $28^{\text {th }}$ January 2020. (Online Article). Available from: https://apps.who.int/iris/handle/10665/330893. [Last Accessed on $25^{\text {th }}$ January, 2021]

35. Lu B, Huang Y, Huang L, Li B, Zheng Z, Chen Z, et al. Effect of mucosal and systemic immunization with virus-like particles of severe acute respiratory syndrome coronavirus in mice. Immunology 2010;130:254-61.

36. Indian Council of Medical Research. Recommendation for Empiric use of Hydroxy Chloroquine for Prophylaxis of SARS-CoV-2 Infection.

(Online PDF). Available from: 
https://www.icmr.gov.in/sites\%20/default/files/upload \%2odocuments/HCQ Recommendation 22March\%2of inal MM V1.pdf. [Last Accessed on $25^{\text {th }}$ January, 2021] 37. Gautret P, Lagier JC, Parola P, Meddeb L, Mailhe M, Doudier B, et al.Hydroxychloroquine and azithromycin as a treatment of COVID-19: results of an open-label non-randomized clinical trial. Int J Antimicrob Agents. 2020;105949.

https://doi.org/10.1016/j.ijantimicag.2020.105949. 38. Marano G, Vaglio S, Pupella S, Facco G, Catalano L, Liumbruno GM, et al. Convalescent plasma: new evidence for an old therapeutic tool? Blood Transfus. 2016;14:152-7.

39. Ather A, Patel B, Ruparel NB, Diogenes A, Hargreaves KM. Coronavirus Disease 19 (COVID-19): Implications for Clinical Dental Care. J Endod. 2020; 46:584-595. https://doi.org/10.1016/j.joen.2020.03.008 40. American Dental Association. ADA Develops Guidance on Dental Emergency, Nonemergency Care. (Online Article). Available from: https://www.ada.org/en/publications/ada-news/2020archive/march/ada-developsguidance-on-dentalemergency-nonemergency-care. Accessed on May 25, 2020. [Last Accessed on $27^{\text {th }}$ January, 2021]

41. American dental association. What Constitutes a Dental Emergency?. (Online Article). Available from: https//www.success.ada.org.files.ADA

COVID19 dental emergency. [Last Accessed on 27th January, 2021]

42. Dental Council of India. Precautionary and preventive measures to prevent spreading of novel coronavirus (COVID-19). (Online PDF). Available from:

http://

dciindia.gov.in/Admin/NewsArchives/L.No. 8855. [Last Accessed on $27^{\text {th }}$ January, 2021]

43. Indian Dental Association. Indian Dental Association's Preventive Guidelines for Dental Professionals on the Coronavirus Threat. (Online article). Available from: https://www.ida.org.in/pdf/IDA Recommendations for Dental Professionals on the Coronavirus Threat.

[Last Accessed on $28^{\text {th }}$ January, 2021]

44. American Dental Association. ADA recommending dentists postpone elective procedures. (Online article). Available from: https://www.ada.org/en/publications/ada-news/2020archive/march/adarecommending-dentists-postponeelective-procedures. [Last Accessed on $28^{\text {th }}$ January, 2021]

45. Centers for Disease Control and Prevention. Infection control: severe acute respiratory syndrome coronavirus 2 (SARS-CoV-2) (Online article). Available from: https://www.cdc.gov/coronavirus/2019ncov/infection-control/control-recommendations.html. [Last Accessed on $28^{\text {th }}$ January, 2021]

46. Government of India. Ministry of Health and Family Welfare (MOHFW). Guidelines for dental professionals in COVID 19 pandemic situation. (Online PDF). Available from: mohfw.gov.in/pdf/DentalAdvisoryF.pdf. [Last Accessed on $28^{\text {th }}$ January, 2021]

47. Centers for Disease Control and Prevention. Stop the Spread of Germs. (Online PDF). Available from: https://www.cdc.gov/coronavirus/2019-

ncov/downloads/stop-the-spread-of-germs.pdf.

49. Xiao WJ, Wang ML, Wei W, Wang J, Zhao J, Yi B, et al. Detection of Sars-CoV and RNA on aerosol samples from SARS patients admitted to hospital. Zhonghua Liu Xing Bing Xue Za Zhi. 2004; 25 :882-5.

50. Kariwa H, Fujii N, Takashima I. Inactivation of SARS coronavirus by means of povidone-iodine, physical conditions, and chemical reagents. Jpn J Vet Res. 2004;52:105-12.

51. Centers for Disease Control and Prevention. Guidance for Dental Settings https://www.cdc.gov/coronavirus/2019-

ncov/hcp/dental-settings.html. [Last Accessed on $28^{\text {th }}$ January, 2021]

52. Li JO, Chen Y, Ting DSW. Novel Coronavirus disease 2019 (COVID-19): The importance of recognizing possible early ocular manifestation and using protective eyewear. Br J Ophthalmol. 2020; 104: 297-98. https://doi.org/10.1136/bjophthalmol-2020315994

53. Siegel JD, Rhinehart E, Jackson M, Chiarello L, the Healthcare Infection Control Practices Advisory Committee. 2007 Guideline for Isolation Precautions: Preventing Transmission of Infectious Agents in Healthcare Settings. (Online article). Available from: https://www.cdc.gov/infectioncontrol/guidelines/isolat ion/index.html. [Last Accessed on $28^{\text {th }}$ January, 2021] 54. Samaranayake LP, Reid J, Evans D. The efficacy of rubber dam isolation in reducing atmospheric bacterial contamination. ASDC J. Dent. Child. 1989;56:442-4.

55. Samaranayake LP, Peiris M. Severe acute respiratory syndrome and dentistry:a retrospective view. J Am Dent Assoc. 2004;13:1292-302.

56. Barenghi L, Barenghi A, Cadeo C, Di Blasio A. Innovation by computer-aided design/computer-aided manufacturing technology: a look at infection prevention in dental settings. Biomed Res Int. 2019; 2019:6092018. https://doi.org/10.1155/2019/6092018.

57. Otter JA, Donskey C, Yezli S, Douthwaite S, Goldenberg SD ,Weber DJ. Transmission of SARS and 
MERS coronaviruses and influenza virus in healthcare settings: the possible role of dry surface contamination. J Hosp Infect.2016; 92:235-50.

58. World Health Organization. Infection prevention and control during health care when novel coronavirus
$(\mathrm{nCoV})$ infection is suspected. Interim guidance.25 January 2020. (Online article). Available from: https://apps.who.int/iris/handle/10665/330674. [Last Accessed on $28^{\text {th }}$ January, 2021]

Cite this article as:

Priyanka, Bhansali SP, Bhansali S, Malhotra Y. Coronavirus Disease 2019: Prevention and Safety in the Dental Office. Int Healthc Res J. 2021;5(1):RV1-RV8. https://doi.org/10.26440/IHRJ/0501.04406

AUTHOR AFFILIATIONS: ( ${ }^{*}$ Corresponding Author)

1. MDS, Medical officer, Health and Family Welfare Department, Himachal Pradesh, India

2. MDS, Assistant Professor, Department of Oral and Maxillofacial Surgery, RUHS College of Dental Sciences, Jaipur, Rajasthan, India

3. MDS, Associate Professor, Department of Prosthodontics, RUHS College of Dental Sciences, Jaipur, Rajasthan, India

4. MDS (Orthodontics and Dentofacial Orthopaedics), Consultant Orthodontist, Kangra, HP, India 